\title{
Socio-psychological motivation of academic teaching staff
}

\author{
Anna Fedyaeva ${ }^{1, *}$, Olga Lezhnina $^{2}$, Anastasia Marinina $^{2}$ and Daria Belinskaya ${ }^{3}$ \\ ${ }^{1}$ Vyatka State University, 36, Moskovskaya str., 610000, Kirov, Russia \\ ${ }^{2}$ Vyatka State Agricultural Academy, 133, October Avenue, 610017, Kirov, Russia \\ ${ }^{3}$ Moscow State University of Civil Engineering, 26, Yaroslavskoye Shosse, 129337, Moscow, Russia
}

\begin{abstract}
The article deals with the development of a motivation system, which includes different elements of motivation for the university staff. The article clarifies the concept of "socio-psychological motivation", identifies factors that influence labor motivation. To test the hypothesis, the author has presented the project to increase the socio-psychological motivation in the professional activities of the academic teaching staff, which can be applied at university.
\end{abstract}

\section{Introduction}

Modern time is characterized by an active reform of the higher education system, there are new requirements to the teacher as a specialist. We should consider that the effectiveness of the labor contribution of teachers depends not only on competence, but also on the motivation of their work. Despite a lot of different theoretical and practical research, the problem of motivation of university staff hasn't been studied properly.

The work of a university teacher is very complicated. It combines teaching, scientific, methodological, educational and organizational functions. The nature and content of the work of university teachers are seriously influence by changes that contradict the current motives and incentives of teaching. Therefore, there is a need to bring the process of organization and management of the work of pedagogical staff in accordance with the new economic conditions for universities.

The problem of teaching staff motivation is covered in various aspects: in relation to the problem of motivation of labor behavior of teachers [1,9]; in relation to the problem of management psychology [2], from the standpoint of the basics of managerial activity and the assessment of teachers' behavior in the face of changes [3]; in relation to the problem of overcoming resistance to change [4,10-11]; from the standpoint of examination of teacher's innovative activity [5].

However, at present, the methodology and methods of the relationship of incentives and motives in the search and construction of an effective motivation system for the university staff is not fully developed. It explains, in particular, the existing shortcomings in the study of the nature and content of teaching work, its functions, the construction of optimal

\footnotetext{
* Corresponding author: esenia_web@mail.ru
} 
payment systems, the determination of the motives of teachers' labor activity, which undoubtedly influence the results of the formation of human capital.

Motivation has economic, social and moral functions.

1. The economic function is expressed in the fact that labor motivation helps to increase production efficiency, that is increasing labor productivity and product quality.

2. The moral function is determined by the fact that incentives to work form an active life position, a moral climate in society. At the same time, it is important to ensure the correct and justified system of incentives, taking into account tradition and historical experience.

3. The social function means the formation of the social structure of society through a different level of income, which largely depends on the impact of incentives on different people. Besides, the formation of needs, and as a result, the development of personality are determined by the formation and stimulation of labor in society.

Based on these factors, we can conclude that each person has a certain motivation, which depends on his individual characteristics. The knowledge and study of employee motivation factors is important for the leader, as this is the basis for comparing the interests of the employee and the organization, as well as for developing an effective motivation system.

Table 1. Factors influencing labor motivation.

\begin{tabular}{|c|c|c|}
\hline $\begin{array}{c}\text { Individual } \\
\text { characteristics }\end{array}$ & Nature of work & Description of the situation \\
\hline $\begin{array}{l}\text { - Gender and age } \\
\text { - Education and } \\
\text { qualifications } \\
\text { - Work experience in } \\
\text { the organization } \\
\text { - Labor values } \\
\text { - Leading needs }\end{array}$ & $\begin{array}{l}\text { - The complexity and responsibility of } \\
\text { the work; } \\
\text {-The degree of worker's } \\
\text { independence; } \\
\text {-The degree of worker's } \\
\text { responsibility; } \\
\text {-The presence of feedback; } \\
\text {-The degree of routine work }\end{array}$ & $\begin{array}{l}\text { 1. Organizational context } \\
\text {-motivation system; } \\
\text {-information system; } \\
\text {-organizational culture; } \\
\text {-management methods; } \\
\text {-working conditions. } \\
\text { 2. The working environment } \\
\text {-colleagues; } \\
\text {-subordinates; } \\
\text {-senior managers. }\end{array}$ \\
\hline
\end{tabular}

The traditional salary system for educational institutions of higher education is based on the tariff scale and consists of: official salary, additional payments, bonuses, incentive payments and financial assistance (Figure 1). 


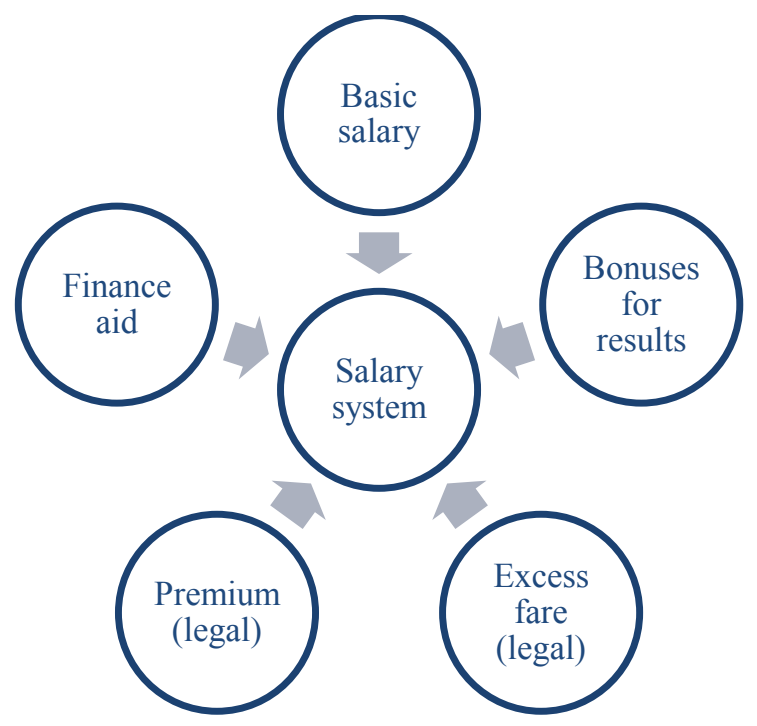

Fig. 1. The salary system of a teacher at a Russian university.

A significant disadvantage of wages on the tariff scale is its low differentiation, which undermines the work motivation of the employee. The system doesn't take into account an attitude of a particular teacher to work, the effectiveness and quality of his work.

The study of the motivation system of university staff had three stages. They are shown in Figure 2.

The main types of work:

- analysis of the existing payment system;

- analysis of the motivation system at Vyatka State University.

1. Organization of data collection. Studying staff in order to draw up a general portrait. Studying needs of university staff.

2. Diagnosis of the current motivation system. Analysis of the level of wages and existing methods of motivation.

3. Development of directions to improve the system of socio-psychological motivation.

Fig. 2. Stages of studying the system of motivation of university staff.

Thus, the purpose of our research is to justify a project to increase socio-psychological motivation for the university teachers. A properly constructed system of motivation for the teaching staff, the use of various methods of motivation will fully contribute to the formation of professional staff and, as a result, increase the effectiveness of the educational organization, achieve a high level of competitiveness in the educational services market. 


\section{Methods}

For effective management of personnel motivation methods, they need to be investigated and evaluated. At the same time, measuring methods of motivation is a complex methodological work.

The author used the following psychological techniques:

1) Motives for choosing the teacher's activities (the author is E.P. Ilyin) [6]. The technique is used for a qualitative analysis by a teacher of the motivational structure of his pedagogical activity, to identify the most significant reasons for choosing a teacher's profession.

2) Methodology of N.V. Zhurin and E.P. Ilyin [7]. The technique identifies the degree of teachers' satisfaction with their profession and various aspects of their professional activities.

3) Questionnaire "Diagnosis of the level of emotional burnout" by V.V. Boiko [8]. The technique allows to diagnose the mechanism of psychological defense in the form of a complete or partial exclusion of emotions in response to selected traumatic effects.

The object of the study is the university staff ( 250 teachers) of Vyatka State University.

The main part of the teaching staff $(62 \%)$ is made up of employees who took part in the research and are PhDs and associate professors, 23\% do not have a degree, $7 \%$ of teachers are professors. Accordingly, the teaching staff has higher education and systematically undergoes continuing education courses.

The basis of the staff is $40-50$-year old teachers (114 people), the smallest group is employees under 25 (5 people), or $2 \%$ of the total number. The group of teachers who are more than 50 years old is not very large ( 19 people), $7 \%$ of the total number.

Information obtained during the study is the subjective opinion of the respondents. Questionnaires were sent by e-mail to university staff, so the study is thematic in nature and has a very limited selection.

\section{Results}

The implementation of any project (innovation) takes place in an environment that has a direct impact on it. The project environment, which includes a set of external and internal factors that contribute to or interfere with the achievement of the project goals, is called the project environment.

SWOT analysis is presented in Table 2 .

Table 2. SWOT-analysis.

\begin{tabular}{|l|l|l|}
\hline & \begin{tabular}{l}
\multicolumn{1}{|c|}{ Possibilities: } \\
Increase staff income; \\
the team spirit of the staff; \\
opportunity to improve the non- \\
material motivation of the staff
\end{tabular} & $\begin{array}{l}\text { Threats: } \\
\text { Staff turnover; } \\
\text { emotional burnout of the staff; } \\
\text { teachers' dissatisfaction with } \\
\text { management practices }\end{array}$ \\
\hline $\begin{array}{l}\text { Advantages: } \\
\text { Good reputation of } \\
\text { the university; } \\
\begin{array}{l}\text { Highly qualified } \\
\text { staff. }\end{array}\end{array}$ & $\begin{array}{l}\text { Develop a system of motivation for } \\
\text { teaching staff to retain highly } \\
\text { qualified employees and increase the } \\
\text { performance of scientific and } \\
\text { economic activities }\end{array}$ & $\begin{array}{l}\text { The platform for discussing issues } \\
\text { of social partnership with } \\
\text { authorities }\end{array}$ \\
\hline $\begin{array}{l}\text { Disadvantages: } \\
\text { Weak motivation } \\
\text { system }\end{array}$ & $\begin{array}{l}\text { Systematic monitoring and diagnosis } \\
\text { of the needs and moods of the staff }\end{array}$ & $\begin{array}{l}\text { Monitoring the interactions of } \\
\text { structural units. }\end{array}$ \\
\hline
\end{tabular}

The study revealed that the existing system of motivation is assessed by the teaching staff as ineffective, since only material motivation methods (implementation of an effective 
contract) are used. More than $80 \%$ of the teachers consider that an effective contract is difficult to fulfill in a modern market economy. The activities of both the university and the teacher are commercial in nature, which is based on additional earnings, and not the educational process.

It is important that every university teacher could see that the result of his specific activity leads to the achievement of common goals. It simultaneously satisfies three aspects:

- social (it is important for a person to recognize himself as a member of a group of people),

- to know you are demended (the principle of "who, if not me" applies),

- confidence in the future (a clear understanding of the relationship "result-reward").

Another independent and quite powerful motivator is the liberation of initiative and increased responsibility for the overall result of activities. In other words, the healthy initiative of employees must be encouraged in both tangible and intangible ways. But at the same time, employees should not forget about their own responsibility.

Material remuneration remains one of the main methods of encouragement and today it plays an important role in the labor activity of any employee. There is a practice of university additional payments to the staff for using interactive learning technologies and innovative developments (the introduction of new educational programs, courses and disciplines, new teaching methods) in the educational process. The size of such remuneration should be differentiated depending on the degree of using active learning technologies (Table 3).

Table 3. Remuneration ranking according to the degree of using interactive learning technologies.

\begin{tabular}{|l|c|}
\hline \multicolumn{1}{|c|}{ Approach to the organization of the educational process } & $\begin{array}{c}\text { Teacher's bonus } \\
\text { (percentage of } \\
\text { salary) }\end{array}$ \\
\hline $\begin{array}{l}\text { The use of active forms of learning is partial. The proportion of active } \\
\text { learning methods is up to } 30 \% \text { of the total number of hours }\end{array}$ & $10 \%$ \\
\hline $\begin{array}{l}\text { The entire educational process is built on active forms and teaching } \\
\text { methods. The proportion of active learning methods is up to } 60 \% \text { of the } \\
\text { total number of hours }\end{array}$ & $15 \%$ \\
\hline $\begin{array}{l}\text { The educational process is based on using copyrighted methods of } \\
\text { active learning. The proportion of active learning methods is up to } 90 \% \\
\text { of the total number of hours }\end{array}$ & $20 \%$ \\
\hline
\end{tabular}

Table 4 presents diverse elements of pedagogical activity.

Table 4. The teaching staff motivation system that considers diverse elements of pedagogical activity.

\begin{tabular}{|l|l|}
\hline \multicolumn{1}{|c|}{ Characteristics of the staff motives } & \multicolumn{1}{c|}{ Methods of the staff motivation } \\
\hline $\begin{array}{l}\text { Satisfaction of material, moral and } \\
\text { social needs of teachers }\end{array}$ & $\begin{array}{l}\text { Providing social guarantees for university teachers } \\
\text { (systematic continuing education, medical service, } \\
\text { nutrition, housing) }\end{array}$ \\
\hline $\begin{array}{l}\text { Improving the level of teachers' } \\
\text { professionalism }\end{array}$ & $\begin{array}{l}\text { Training for postgraduate studies, a competitive } \\
\text { mechanism for the distribution of funding, assessment } \\
\text { of the scientific potential of teachers by formal } \\
\text { indicators }\end{array}$ \\
\hline $\begin{array}{l}\text { Material and technical and } \\
\text { information support for the teacher's } \\
\text { workplace }\end{array}$ & $\begin{array}{l}\text { Providing Internet access for each teaching staff, } \\
\text { updating the material and technical base in classrooms }\end{array}$ \\
\hline
\end{tabular}




\begin{tabular}{|l|l|}
\hline Improving pedagogical technologies & $\begin{array}{l}\text { Prizes for the use of interactive learning technologies in } \\
\text { the educational process }\end{array}$ \\
\hline $\begin{array}{l}\text { Meeting the need for teacher } \\
\text { participation in the management of the } \\
\text { educational process at the university }\end{array}$ & $\begin{array}{l}\text { Informing teachers about the goals and objectives of the } \\
\text { university, the change and the state of affairs at the } \\
\text { university. Providing teachers (within the framework of } \\
\text { established norms) with greater freedom in planning } \\
\text { various types of pedagogical activity, in determining } \\
\text { the content of both their training courses and the subject } \\
\text { of scientific research. }\end{array}$ \\
\hline $\begin{array}{l}\text { Satisfaction with the quality of } \\
\text { management of the university } \\
\text { administration by the process of the } \\
\text { teacher's activity at the university }\end{array}$ & $\begin{array}{l}\text { Democratic management style, the implementation of a } \\
\text { systematic and formalized assessment of faculty } \\
\text { according to clearly defined criteria. Planning and } \\
\text { selection of events for professional development and } \\
\text { staff mobility, taking into account the needs and } \\
\text { professional abilities of teachers, the organization of the } \\
\text { workplace taking into account the requirements of the } \\
\text { management. }\end{array}$ \\
\hline
\end{tabular}

"The study of teachers' satisfaction with their profession and work" has shown that:

$56.8 \%$ of respondents are dissatisfied with wages. More than half of the university teachers are confident that their activities do not correspond to the remuneration received.

$41.6 \%$ of respondents are dissatisfied with the attitude of management to staff, as often important information is not timely delivered to them.

$72 \%$ of the respondents noted that the material and technical base of the university does not meet the requirements of the university, the management expresses the wish that interactive forms of conducting training sessions be introduced into pedagogical activity, but the classrooms are not fully equipped with technical facilities.

$65.2 \%$ of teachers are confident that they cope with their job responsibilities and are satisfied with the results of their work, and respondents also noted that wages are rarely indexed.

In the course of the study, we used the method of V.V. Boiko in order to determine the emotional state of faculty. The results of the study have shown that:

$31 \%$ of teachers feel "they are in caged" and experience a "reduction in professional duties"

$21 \%$ demonstrate "personal detachment"

$17 \%$ have "emotional detachment"

Analyzing the results, we can conclude that the staff of Vyatka State University is characterized by emotional burnout.

\section{Discussion}

The staff motivation system that takes into considers the diverse elements of pedagogical activity is presented in Table 5 .

Table 5. The staff motivation system that takes into considers the diverse elements of pedagogical activity.

\begin{tabular}{|l|lllc|}
\hline Characteristics of the staff motives & \multicolumn{4}{|c|}{ Methods of the staff motivation } \\
\hline $\begin{array}{l}\text { Satisfaction of material, moral and } \\
\text { social needs of teachers }\end{array}$ & $\begin{array}{l}\text { Providing } \\
\text { (systematic }\end{array}$ & continuing education, medical & service, \\
\hline
\end{tabular}




\begin{tabular}{|l|l|}
\hline & nutrition, housing) \\
\hline $\begin{array}{l}\text { Improving the level of teachers' } \\
\text { professionalism }\end{array}$ & $\begin{array}{l}\text { Training for postgraduate studies, a competitive } \\
\text { mechanism for the distribution of funding, assessment of } \\
\text { the scientific potential of teachers by formal indicators }\end{array}$ \\
\hline $\begin{array}{l}\text { Material and technical and } \\
\text { information support for the teacher's } \\
\text { workplace }\end{array}$ & $\begin{array}{l}\text { Providing Internet access for each teaching staff, updating } \\
\text { the material and technical base in classrooms }\end{array}$ \\
\hline Improving pedagogical technologies & $\begin{array}{l}\text { Prizes for the use of interactive learning technologies in } \\
\text { the educational process }\end{array}$ \\
\hline $\begin{array}{l}\text { Meeting the need for teacher } \\
\text { participation in the management of } \\
\text { the educational process at the } \\
\text { university }\end{array}$ & $\begin{array}{l}\text { Informing teachers about the goals and objectives of the } \\
\text { university, the change and the state of affairs at the } \\
\text { university. Providing teachers (within the framework of } \\
\text { established norms) with greater freedom in planning } \\
\text { various types of pedagogical activity, in determining the } \\
\text { content of both their training courses and the subject of } \\
\text { scientific research. }\end{array}$ \\
\hline $\begin{array}{l}\text { Satisfaction with the quality of } \\
\text { management of the university } \\
\text { administration by the process of the } \\
\text { teacher's activity at the university }\end{array}$ & $\begin{array}{l}\text { Democratic management style, the implementation of a } \\
\text { systematic and formalized assessment of faculty according } \\
\text { to clearly defined criteria. Planning and selection of events } \\
\text { for professional development and staff mobility, taking } \\
\text { into account the needs and professional abilities of } \\
\text { teachers, the organization of the workplace taking into } \\
\text { account the requirements of the management. }\end{array}$ \\
\hline
\end{tabular}

\section{Conclusion}

Socio-psychological motivation allows employees to create sense of ownership and affection in the workplace.

An effective staff motivation system at the university is an important and difficult issue. Modern management has a rich set of tools to influence the employee. Motivation is the most important concept in the approach to human behavior in the workplace. Knowledge of the mechanism of motivation is necessary in practice. It helps to distribute and plan work.

An integrated system of socio-psychological motivation is manifested in increasing the satisfaction of the teaching staff with material rewards, working conditions, and conditions of self-expression. Also, the proposed system provides a link between productivity and remuneration, the formation of teachers' feelings of employee involvement in the university, providing a feedback mechanism with the employee based on their desires and needs. Practical experience shows that investing in human capital leads to increasing productivity.

This study is preliminary, further study of the issues of motivation at Vyatka State University is required.

The next stage of the research may be the study of the process of formation of organizational commitment, the study of motivation for the three-dimensional typology of teachers, assessment and impact on the quality of the educational process by consumers, etc.

\section{References}

1. O.N. Allin, Personnel for an effective business. Selection and motivation of staff (M., Genesis, 2017)

2. M. Upter, Beyond personality traits. Reversible Theory of Motivation (M., Media, 2016) 
3. A.V. Varenov, Personnel motivation. game or work (M., Speech, 2017)

4. A.V. Varenov, Personnel motivation: game or work. What do we do during working hours at the workplace? (M., Speech, 2016)

5. E. Vetluzhskih, Motivation and remuneration. Tools. Techniques. Practice (M., Alpina Publisher, 2018)

6. E. Dashkova, Innovative approaches to managing staff motivation (M., LAP Lambert Academic Publishing, 2017)

7. A.V. Bataev, A.A. Gorovoy, A.B. Mottaeva, Proceedings of the 32nd International Business Information Management Association Conference, IBIMA 2018 - Vision 2020 (2018)

8. The art of recruitment. How to evaluate a person correctly in an hour (M., Harvest, 2018)

9. Yu.G. Odegov, Staff motivation. Tutorial. Practical tasks (practicum) (M., Alfa-press, 2016)

10. A. Sizov, Pocket Guide of the Great Leader, or 55 ideas for staff motivation (Moscow, High School, 2018)

11. Reinhard Sprenger, Myths of motivation (Moscow, Science, 2017) 